This is the post print version of the article. Contesting Coloniality Special Issue http://www.journals.uchicago.edu/doi/abs/10.1086/690458

Silova, Iveta, Millei, Zsuzsa \& Piattoeva, Nelli (2017) Interrupting the Coloniality of Knowledge and Being in Comparative Education: Post-Socialist and Post-Colonial Dialogues after the Cold War. Comparative Education Review 61(S1) (May 2017 Supplement) S74-S102 http://dx.doi.org/10.1086/690458

\title{
Interrupting the Coloniality of Knowledge Production in Comparative Education: Post-Socialist and Post-Colonial Dialogues after the Cold War
}

\author{
Iveta Silova, Zsuzsa Millei, and Nelli Piattoeva
}

\begin{abstract}
This article explores the coloniality of knowledge production in comparative education in and about (post)socialist spaces of Southeast/Central Europe and former Soviet Union after the Cold War. We engage in a particular form of decoloniality, or what Walter Mignolo terms delinking. Delinking challenges the "emancipatory project" of modernity and colonial relations and sets out to decolonize knowledge, thus interrupting dominant understandings about the organization of the world, society, and education. We do not propose to replace this epistemology with another or others, but take it as the target of critique in a world where many different views could co-exist on a nonhierarchical basis. Our critique is threefold. First, we engage in rethinking and rewriting the socialist past(s) through new and multiple frames to reveal potential possibilities for imagining multiple post-socialist future(s). Second, we show the relations and the intertwined histories of "different worlds," thus unsettling the established spatial partitions of the world. Third, we examine how coloniality has shaped our own identities as scholars and discuss ways to reclaim our positions as epistemic subjects who have both the legitimacy and capacity to look at and interpret the world from our own origins and lived realities. We believe that this kind of delinking fractures the hegemony of Western-centric knowledge, enabling comparative education to gain a global viewpoint that is more inclusive of different voices.
\end{abstract}

The fall of the Berlin Wall in 1989 held the promise of opening new dialogues between the formerly separated three worlds. However, soon after 1989, this space closed and the possibilities for dialogue became subsumed into broader globalization debates, positioning the post-socialist region of Southeastern/Central Europe and its education systems on a "journey" towards the West and (re)directing knowledge flows from West to East and North to South (Silova 2014). This closure is symptomatic of a well-established tradition in comparative research to use the West as a single yardstick for understanding the world. ${ }^{1}$ Ranging from modernization theory to world culture theory to postmodern theory, the discussion of nonWestern education systems is often framed as "an aberration to the European 'norm' either in respect to their origins or to the extent to which they demonstrate "postmodern' characteristics" (Tikly 1999, 617). While offering an interpretation of broad trends associated with globalization processes, the preference for Western-centric theoretical frameworks and methodological approaches (re)produces a familiar yet inevitably one-sided image of the world. At the same time, it homogenizes the multiplicity of non-Western realities, devalues epistemic differences, and overlooks alternative interpretations (Connell 2007; Takayama et al. 2016). We are thus painfully reminded that, in the aftermath of the Cold War, the foundation of modern knowledge production remains both "territorial and imperial" (Mignolo \& Tlostanova 2009, 206; see also Connell 2007).

\footnotetext{
${ }^{1}$ See Tikly (1999) and Cowen (1996) for a targeted critique of comparative education in the context of modernity project.
} 
In comparative education, the initial critique of Western hegemony emerged as a result of decolonization struggles of the global south (Altbach \& Kelly 1978), as well as a response to the persisting colonial legacies in education and subsequent international development assistance grounded in Western perspectives (Hickling-Hudson 1989, 2007a; Cowen 2006; Samoff 1999; Tikly 2004; Tikly and Bond 2013). However, the end of the Cold War made it clear that colonial patterns of power (or coloniality) extend beyond post-colonial administrations, "defin[ing] culture, labor, intersubjective relations, and knowledge production" everywhere (MaldonadoTorres 2007, 243). As Mignolo $(2011,53)$ explains, the project of decolonization has mutated into decoloniality towards the end of the Cold War, suggesting that Western hegemony has to be addressed not only as a geographical issue aimed at expelling the colonizer from colonized territories, but also as an epistemic one aimed at the decolonization of knowledge. In this context, decoloniality entails both "the analytic task of unveiling the logic of coloniality," which constitutes the Western modernity project, ${ }^{2}$ and "the prospective task" of building a world in which many alternative worlds can coexist (Mignolo 2011, 54).

Our goal is to contribute to this project by revealing the coloniality of knowledge production in comparative education in and about post-socialist spaces of Southeast/Central Europe and former Soviet Union (in short post-socialist knowledge production). We engage in a particular form of decoloniality, or what Mignolo (2007) terms delinking. Delinking challenges the "emancipatory project" of modernity and colonial relations, and sets out to de-colonize knowledge, thus interrupting dominant understandings about the organization of the world, society, and education. ${ }^{3}$ We do not propose to replace this epistemology with another or others, but take it as the target of our critique in a world where many different views could co-exist on a nonhierarchical basis (Tlostanova 2012; Tlostanova et al. 2016). In other words, delinking also means overcoming "the Western agonistic principle of making theories and practices compete for dominance" (Tlostanova et al. 2016, 14; Mignolo 2007) and thus enables comparative education to gain a global viewpoint that is more inclusive of different voices.

To delink from the logic of coloniality that shapes post-socialist knowledge production, we first discuss ways in which coloniality operates in post-socialist spaces. We then operationalize Mignolo's project of delinking $(2007,2013)$ in three ways. First, we attempt to complicate the past in order to overcome singular histories constructed from the Cold War binary frameworks of the East/West divide. We believe that multiple histories (or multiple starting points) have the

\footnotetext{
2 Coloniality represents "the darker side of Western modernity" upon which Western empires founded themselves, as well as justified their imperial expansion and intervention across the world - whether as Christianity, civilization, modernization, and development after the World War II or market democracy after the fall of the Berlin Wall (Mignolo 2001). Because "coloniality is constitutive and not derivative of modernity," it is often written as "modernity/coloniality": "The slash (/) that divides and unites modernity with coloniality means that coloniality is constitutive of modernity: there is no modernity without coloniality" (Mignolo 2015, 2).

${ }^{3}$ Mignolo (2007) argues that both European and socialist traditions of the European enlightenment carry a universal emancipating claim, terming it the "myth of modernity." The concept of emancipation is based on the three revolutions of the 18th century Europe that set the bourgeoisie free. The revolutions translated the idea into "the universal term of 'humanity' (freedom) and set ... the stage to export emancipation all over the world" (Mignolo 2007, 455).
} 
potential to disrupt the linearity and singularity of post-socialist trajectories outlined by some social science and comparative education research. Second, we aim to show the relations and the intertwined histories of "different worlds," thus unsettling the established spatial partitions of the world and questioning the very logic of modernity/coloniality. Third, we examine how coloniality has shaped our own identities as scholars and discuss ways to reclaim our positions as epistemic subjects who have both the legitimacy and capacity to look at the world from our own origins and lived realities. Before we proceed with our argument, however, we will make some conceptual and methodological notes.

\section{Conceptual and Methodological Notes}

"Post-socialism" is a questionable umbrella term that can homogenize the geopolitical diversity of the region and the variety of socialist and post-socialist imaginaries, conditions, and paths among different countries of Southeast/Central Europe and the former Soviet Union. "Postsocialism" can thus divorce these societies from their unique histories, current conditions, and prospects in Europe and the world (Tlostanova 2012). We acknowledge the limitations of this term as much as we also emphasize the impossibility of uncontroversial, universalizing terminology in general, and choose to use it less in our paper. Instead we talk about post-socialist spaces. This allows for the coexistence of multiple post-socialist spaces, places, and times, and expresses their relatedness based on some political, geographical, economic, and/or historical commonalities. Thus, our application of the term is akin to the notion of the 'South' in "Southern Theory" in that it, too, acts as a geographic and temporal marker "for the regions of the world that continue to live with the consequences of colonial [and post-socialist] legacy in culture, subjectivity and knowledge" (Takayama et al. 2016, 5). In addition, echoing the notion of the 'South,' post-socialism is an epistemological marker in that we perceive the region as a source of unique but often un- or mis-recognized knowledge developed through layered and localized experiences of socialism and coloniality. Finally, "post-socialism" has a political dimension in that it carries a historical legacy of the Cold War and thus serves as a reminder of the artificial division of the world which still perpetuates existing inequalities and imaginaries, but could potentially encourage a sense of commonality and solidarity among those who share the postsocialist condition in its various forms.

Another term that needs clarification is race. Race and racism, so central to post-colonial investigations (Fanon 195; Quajino 2007), have been complicated in socialist spaces by a focus on class and ideology, and to a lesser extent ethnicity (Tlostanova 2012). As Chari and Verdery (2009) explain, even though state sanctioned racism under socialism employed racial technologies and expertise to differentiate spaces and populations through their contrasting propensities to life and death, these followed less the lines of racial 'othering' apparent in former colonies. In this way, we observe an enlarged notion of race in socialist and post-socialist contexts in a similar manner to what Balibar proposed (in Balibar \& Wallerstein 1991), whereby racism shifts to a new modality, to a 'racism without races.' As he explains, the three institutional anchors of racism - biopolitics (treating human material as exploitable), xenophobia (representing certain identities or religious, cultural or biological purity as essential to the preservation of national unity), and representation of groups of humans in terms of competition 
for domination - have not disappeared but rather have been reconfigured and coupled with growing intolerance and identity politics (Balibar 2015). For example, the Yugoslavian brand of racism was directed to those who were one rank lower in the economic and geographic position (Hladík 2013). In post-socialist societies, this new modality of racism becomes visible in the new racism against migrants or when the offspring of migrants are categorized as 'second' or 'third generation' to maintain their 'foreign identity' (Jusová 2016).

The continuity of coloniality through these racial/cultural lines creates hierarchies in comparative education knowledge production and attaches itself to scientific authority. As the next section reveals, these lines of othering contribute to devaluing scholarly work emerging from nonWestern, including post-socialist spaces. In addition to revealing the coloniality of knowledge production in comparative education, we also seek to offer some insights into our own positionings and relations as 'raced' comparative education scholars working in the borderlands between the East/West/North/South. We use the tools of "border thinking" to disrupt our positionings and engage in mutual learning practices in order to transverse halted dialogues. As Escobar $(2007,188)$ summarizes, border thinking "has to do with the re-articulation of global designs by and from local histories; with the articulation between subaltern and hegemonic knowledge from the perspective of the subaltern." To pursue this, we use a parallel, embedded text - which we will refer to as 'juxta' - to introduce a voice other than our academic voice, speaking from different positions and enabling us to say what we would normally not say in an academic article. 'Juxta' thus disturbs "the tranquility with which we usually 'consume' qualitative research and its objects and subjects” (Petersen 2015, 148).

By using juxta, we do not aim to create a coherent narrative or speak the truth of consciousness or experience. Rather we set juxta to rub against hegemonic discourses and knowledge claims. We share stories and reflections as part of juxta to complicate, interrupt, or make ambivalent knowledge claims produced through colonial relations of power. At the same time, our intention is to give voice to those less privileged accounts that we have selected to include from among many possible accounts. Methodologically, we proceeded with juxta as a kind of 'plugging-in' proposed by Jackson \& Mazzei (2012) (who followed Deleuze \& Guattari's (1987) phrase). Plugging-in is a process in which we insert or set to work ideas, emotions, fragments, theory, analysis, and selves, to challenge processes that seamlessly reproduce coloniality of knowledge. In juxta, we 'plugged' into our text tomes of theory, literature reviews, interview data from our previous research, stories of working with other researchers and bureaucrats, and our personal reactions to reading academic texts. As what we have plugged-in works its ways - interrupts, distorts or supports the main text - our overall paper becomes a process of making and unmaking. For example, when we necessarily point to binaries in our critique and hence reproduce them, our juxta helps to undo those binaries by making them ambivalent. As text and juxta constitute one another, they resist simplification and create new ways of thinking about knowledge production and our identities.

As comparative education scholars born and raised in Latvia, Hungary, and Russia, and 
currently positioned in different "Western/Northern" universities that hold unequal positions within the global political economy and knowledge production in research, we have in various ways personally encountered the coloniality of knowledge. These events have prompted us to construct a space for what Tlostanova and her colleagues (2016) have termed "collaborative praxis as a methodological and theoretical intervention" (2). We thus engage in a long-needed dialogue among ourselves and between us and comparative education literature to bring into conversation the ambivalent ways of being post-socialist subjects. To be 'other' is not only to be the object of another's gaze within the dominant narrative. Speaking the voice of the 'other' fractures conversations by referencing untold social and political histories. Thus, we aim to interrupt the dominant developmental narratives that portray post-socialist spaces, as well as academics located in or associated with these spaces. Following Tlostanova et al. (2016), we start from our own multiple positionings and explore "our own body-politics and geopolitics of knowledge, being and perception" (5) through personal stories in various inter-crossing borderlands as post-colonial and post-socialist scholars.

Iveta: Growing up in Soviet Latvia, I was a part of an ethnically diverse and bilingual family. I quickly learned to function in the "border-zone" of different political, linguistic, and ethnic identities, easily moving in and out of spaces depending on particular circumstances and contexts. My identity became more complicated when I moved to the US to complete masters' and $\mathrm{PhD}$ degrees and then moved again to Central Asia and the Caucasus to begin my academic and professional career there. I found myself in a much broader "border zone," which now expanded to include global, national, and subnational identities. In Central Asia, I was perceived as "one of ours" by my local colleagues because of our shared Soviet history and, at the same time, as a legitimate member of the international development community by "Western" colleagues because of my degree from an American university. As I moved "West" to become a university professor in the United States, my previous academic and professional experiences were quickly discounted as not "Western enough" so my tenure clock had to start from zero and my academic identity had to be rebuilt from scratch. Shifting between these different roles has been both fascinating and complicated. I always felt fortunate to be a part of the different "worlds" even though I knew that I never fully belonged to any of them. I always have been and continue to be at the "borders."

Zsuzsa: I was born and earned my Masters degree in Hungary. After migrating to Australia I enrolled in a $\mathrm{PhD}$ program. My student peers suggested to me to rather open a restaurant to gain financial stability in Australia, which I understood as an accepted trajectory for migrants to establish themselves in a new country. My $\mathrm{PhD}$ focused on the history of Western Australian early childhood education and I had to be persuaded that there might be value in comparing those developments to socialist Hungarian ones, which I undertook later. I am still somewhat puzzled when other researchers express enthusiasm for my research about socialist Hungary. Teaching at different Australian universities and lecturing about the Australian education system, I was often confronted by students questioning my knowledge simply based on my accent. Other times I was labelled as an "exotic European" who simply soaked up 
continental theorizing. Being "down under" they have not realized my "not so European" origins. When I called Australia my home after 15 years of living there, even my academic colleagues could not restrain their smile: "with this accent, Zsuzsa?" Now that I am researching at a Finnish university, I am simply unable and also unwilling to answer the question where I am from. I am from where my home and multinational family is, always at the border, not here but not there either.

Nelli: I was born and raised in the Westernmost part of the USSR and continued my education across the border in Finland where I currently live and hold an academic tenure. Coming from an ethnically mixed family that throughout the Soviet period experienced state-supported racism, my identity is multi-layered, unstable, and vulnerable due to continuous questioning by the outsiders. Despite the fact that I have lived in Finland for most of my life, I am still perceived as a Russian, an exotic product of Russia's much admired cultural heritage and its shunned political tradition. Sometimes I am also a lucrative international recruitment - "a gift of Mother Russia to us" - as a colleague once remarked. In Russia, where I do most of my fieldwork, my affiliation with a "Western" university can be a focus of admiration or even envy, but also of uncertainty and discomfort as people are unable to position me clearly as either Russian or foreign. I have spent years polishing my theoretical toolbox and skills in English and Finnish languages to satisfy my desire for mastering the "global language" (Takayama 2016) and fitting the general Anglo-American academic ideal, and my non-English speaking institution. I feel neither "Finnish enough" at my home institution nor "AngloAmerican enough" "as a scholar from a university located on the outskirts of Europe, nor "Russian enough" to feel at rest in a place seen by many as my obvious home. Somewhat surprisingly, this feeling of "out-of-placeness" has currently brought me closer to those Finnish colleagues who feel increasingly dislocated and dispossessed by the competitive ethos of the neoliberal university, turning the discomfort of "out-of-placeness," despite its different origins, into an opportunity for re-bonding.

\section{Coloniality of Knowledge After the Cold War}

In What was Socialism and What Comes Next? Verdery (1996) convincingly argues that the Cold War was "a form of knowledge and a cognitive organization of the world" (330). It shaped mutual perceptions and research practices in far-reaching ways, laying down "coordinates of a conceptual geography grounded in East vs. West and having implications for the further divide between North and South" (Verdery 1996, 330). Stemming from the foundations of Western modernity/coloniality, these coordinates were primarily based on dichotomies - such as capitalism/socialism, religious/atheistic, imperialist/liberationist, or good/evil - spatially partitioning the world according to the three-worlds ideology and thus further re-inscribing imperial and colonial difference globally. While the Cold War is over and the "three worlds" no longer exist, the logic of partitioning the world along this epistemological axis perpetuated into the post-Cold War era, reflecting the enduring legacy of Western modernity/coloniality. 
This axis is also prevalent in the current knowledge hierarchizing scholarship and body-politics of comparative education, materializing in practices that privilege Western epistemologies and humanist research ethical codes (Tikly \& Bond 2013), reproduce the hegemonic discourses of 'development' and 'benchmarking' that reinforce the unequal standing of marginalized populations, contribute to their intellectual dependency of non-Western scholars, and put comparative education research at the service of development agencies (Cowen 2006; Samoff 1999; Tikly 2004; Tikly \& Bond 2013). Such practices often exclude non-white, non-Western (female) academics from academic societies and editorial boards of field-specific journals (Hickling-Hudson 2007) and disregard alternative epistemologies, while applying distinctively Western-developed theoretical traditions and categories as interpretative frames for empirical cases far removed from the locations where these vantage points were first developed (Takayama 2016).

During the 1990s, this epistemological axis became instrumental in constructing a historical rupture between socialist past and capitalist present, using the narrative of "crisis" as a central rhetorical device. For example, research studies and policy reports pointed to the rapidly declining funding for education, HIV/AIDS epidemic among youth, the declining status of the teaching profession, the erosion of values, and growing socioeconomic stratification of societies through education (see Lisovskaya \& Karpov 2001; Bodine 2005; Eklof \& Seregny 2005; Silova 2009; Niyozov 2004). Often, the narrative of "crisis" invoked binary conceptual frameworks to understand post-socialist change, whereby Western neoliberal education reform "packages" would be positioned as ideals for emulation (Silova \& Steiner-Khamsi 2008; Silova 2010; Takala \& Piattoeva 2012). Reflecting on education policy documents in post-Soviet Ukraine, for example, Fimyar (2010) explains how policies made use of "traditional binary oppositions such as authoritarian/humanistic, state/civil society, industrial/information-technological [knowledge] society, national nihilism/self-identification, monopoly/decentralization, and totalitarian/ democratization" to emphasize the differences between the socialist and neoliberal systems of rule (82). In this context, the socialist pedagogy was constructed as authoritarian and serving a totalitarian state, concluding that it needed to be eradicated in order to become truly modern (and ultimately truly Western).

Such starkly dichotomous representations of post-socialist education transformations have not been limited to particular countries, but have rather been attributed to the whole post-socialist region of Southeast/Central Europe and the former Soviet Union. For example, Perry's (2003) analysis of 220 policy documents and research studies in 13 countries ${ }^{4}$ reveals that most documents portray post-socialist education systems at the negative end of binaries. She explains that policy documents present the West as "tolerant, efficient, active, developed, organized, and democratic, and the East as intolerant, corrupt, passive, underdeveloped, chaotic, and undemocratic" (Perry 2009, 177). As such, these binary constructions reorient the post-socialist

\footnotetext{
${ }^{4}$ Poland, Czech Republic, Slovakia, Hungary, Slovenia, Lithuania, Estonia, Latvia, Bulgaria, Romania, Ukraine, Belarus, and Russia.
} 
education space within the post-cold war East/West conceptual map, contributing to the perception of the region's marginality vis-a-vis Europe and the West:

The logic of progression embedded in such "maps" builds upon oppositions between communist and neoliberal systems of rule. Conceptual binaries, which present two poles in the map of transition, give the actors a sense of direction and infuse a readily digested meaning into the process of educational reformation. (Perry 2009, 82)

By referencing both the past and the future of education at the same time, policy documents and research studies have thus established a singular path for post-socialist transformations. In this context, the West has been uncritically presented as the embodiment of progress, providing "the normative affirmation of the Western modernity project" (Blokker 2005, 504), while constraining possibilities for imagining other pasts and futures. In essence, we see the coloniality of knowledge production at play here: singular Western models, and abstract global universals more recently, are used as the yardsticks for understanding post-socialist transformations often drawing on racialized hierarchies and epistemologies, and subjugating alternative articulations of post-socialist pasts, presents, or futures.

In "Affective Economies," Sarah Ahmed (2004) explains how emotions create the boundaries of bodies and worlds, where the emotion of hate, such as in nationalism, produces the ordinary as in crisis and the ordinary subject as a victim under the threat of invasion by others in proximity to them. In this way, the very construction and declaration of "crisis," and the emotional field it produces, "transforms it into a fetish object that then acquires a life of its own" (Ahmed 2004, 132). The fear produced by the "crisis" discourse opens up past histories that stick to the present. This intense shared feeling after 1989 has bound societies together as a collective on the Western side of the former Iron Curtain and re-established and maintained a safe distance from the "East." It also produced guiding principles for transforming postsocialist societies towards values of democracy, freedom, and a capitalist economy, setting agendas for international organizations, governments, and academic research. This manyfold economy of the crisis narrative is also visible in our own work (Griffiths \& Millei, 2013; Piattoeva 2010; Silova 2009; Silova et al. 2007). As academics, we ourselves are directly implicated in contributing to the construction and maintenance of the rhetoric of "crisis," thus reproducing binaries that reiterate old divides and fears that keep the other at a distance or lagging, both physically and in knowledge production.

The word "collapse" - often used in describing the geopolitical events of 1989 - produces similar, perhaps even more dramatic affective responses. It invokes the image of a fundamental failure. Of nothing being left behind, a void of morals and values. Of blank slate onto which the values of democracy and market-economy are waiting to be readily written. Similar to the narrative of "crisis," the narrative of "collapse" has established itself perpetually in the academic imaginary. As we were working on this article, the narratives of "collapse" and 
"crisis" kept constantly creeping in our own writing, only to be deleted again and again. These glimpses through the emotionally charged colonial gaze have lent us moments of coziness of belonging and a sense of authority and importance that comes with being part of a dominant discourse.

Coloniality of knowledge production has inadvertently shaped academic identities, simultaneously socializing the non-Western or not-so-Western scholars into the Western norms of thinking and marginalizing them in the knowledge production processes. The process of Western academic socialization primarily occurred through scholarship programs established by Western European and North American governments and foundations to "promote mutual understanding, build democracy, and foster the transition to market economies in Eurasia through intensive academic study and professional training" (Muskie Fellowship program, IREX website, 2016). Since the early 1990s, such programs brought thousands of students from the former socialist countries to pursue degree programs in the US with the expectation that the returning graduates would "share their first hand understanding of American culture and democratic values in their workplaces and communities and take leadership roles in the nonprofit, private, and government sectors" (IREX website, 2016). Those students who were unable to go to the United States or Western Europe had an opportunity to pursue Western type education closer to home. In 1992, for example, Central European University (CEU) was established to encounter the "research tradition of the great American universities" (CEU website, 2015). CEU was conceptualized as "an international university that would help facilitate the transition from dictatorship to democracy in Central and Eastern Europe and the former Soviet Union" (CEU website, 2015). Similar to the US Fellowship programs, CEU graduates were expected to return to their home countries bringing with them a "new" imagination of democracy, democratic institutions, and free market economy.

As these Western trained academics and practitioners returned to their home countries, they often found themselves unable to compete with Western "experts" who occupied dominant positions in the knowledge production field. As Tlostanova (2015) notes, the global North simply refused "to accept the post-Soviet scholar in the capacity of a rational subject" (38). This epistemic asymmetry became clearly visible in the reports written by various international organizations on the status of education in different post-socialist countries. Whether commenting on education reforms in Latvia, Albania, Kosovo, or Tajikistan, Western "experts" consistently concluded that local policymakers and educators were incapable of independently conducting research, articulating policies, or implementing education reforms. Commenting on Kosovo, for example, an OECD (2003) report concluded that "there is a lack of professional capacity in, and strategic vision of, curriculum reform (337). In Albania, "there is a lack of knowledge and skills to aid the reform in the governance of education (OECD 2003, 52) and "a lack a meaningful educational research and policy development capacity important for improving the quality of teacher education (67). In Latvia, "the OECD team is concerned that the MoES [Ministry of Education and Science] is seriously challenged in its capacity to accomplish its current legal mandate" (OECD 2001, 168-169). 
Reading and analyzing these OECD reports can be very personal, especially when they were written after you personally participated in an interview with an OECD expert visiting the country you were born in and later proclaiming you (and your colleagues) as "incompetent." After the first shock subsides, the ways in which coloniality has shaped these reports emerge. In this case, it seems that the defining feature of an "expert" is based on nationality (national culture belonging to the ex-socialist camp) or rather being born in a particular society. This reasoning, however, defies any argument that Western training can overcome epistemological divides, thus contradicting the very attempts to re/train experts of/for post-socialist societies. By disqualifying academic degrees and professional experiences originating in the postsocialist region, these reports construct nation-bound expertise as desirable. Thus, operating as a form of racial technology that differentiates based on national culture by birth, discourses of expertise reinforce the immutability of cultural differences in post-socialist societies.

To exceed our positioning as "nation-bound experts," our identity politics transcend this kind of geopolitics of knowledge. Our identities are grounded in politics, in our experiences of being educated in the West and yet thinking in the exteriority, that is the exteriority of being an Other both in our birth nations and in spaces of Western academia.

Rather than pointing to the challenges of post-socialist transformations, these reports incapacitate local efforts to engage in education reform and explicitly position post-socialist policymakers and educators as passive, ignorant, and incapable of meaningful thought and action. These narratives inadvertently reinforce the power of Western "experts," enabling them to speak for those who supposedly lack expert knowledge to independently determine their own futures (Silova 2010, 2014; Piattoeva 2015). Even when local expertise is called upon, East European scholars are normally expected to provide empirical data and cases, while theorization, abstract thinking or conceptual work is reserved to Western scholars (Salecl 2002; also Tlostanova et al. 2016). Mignolo (2015) refers to this relationship as "epistemic racism":

It is built on classifications and hierarchies carried out by actors and installed in institutions they have themselves created or inherited the right to classify and rank. That is, actors and institutions that legitimize the zero-point of epistemology as the word of God (Christian theology) or the word of Reason (secular philosophy and science). He who does the classifying classifies himself among the classified (the enunciated), but he is the only one who classifies among all those being classified ... Those who are classified as less human do not have much say in the classification (except for dissent), while those who classify always place themselves at the top of the classification. (xv)

It is not surprising then that such an epistemic relationship has triggered scholars to provocatively ask: "Can the Post-Soviet Think?" (Tlostanova 2015), joining the chorus of other post-colonial scholars defying the established epistemic asymmetry: "Can Asians Think?" (Mahbubani 2001) or "Can Non-Europeans Think?" (Dabashi 2015). While the unanimous 
answer is "Yes, they can!", as convincingly argued by Walter Mignolo in a foreword to Dabashi's (2015) book, the intellectual critique points out that delinking from a singular logic, process, and path established by modernity/coloniality offers the potential to simultaneously open up for various alternative histories and visions of education in post-socialist spaces.

\begin{abstract}
"Epistemic racism," which crosses the lines of social and institutional spheres, presents North American and European (French and Anglo-Saxon) philosophy and social science as universal, naturalizing certain ways of thinking and producing knowledge (Mignolo 2015, x.). "Epistemic racism" also permeates the foundations of comparative education, although it has been increasingly critiqued recently (e.g. Gobo 2011; Takayama 2011, 2015; Rappleye \& Komatsu 2016). Seminal publications originating in Western academic centers and European philosophy (mostly delivered by white male academics) drive theoretical discussions in comparative education (Takayama 2011). In this context, it is not surprising that the way to gain acknowledgement and legitimacy as a scholar is quite limited to those who work within particular theoretical and methodological traditions. For example, many comparative education researchers choose to frame their analyses in Western theoretical frameworks or abstract globalization debates, offering their own research as case-studies to illustrate the universality of Western theory and their explanations of post-socialist or post-colonial presents. In some of our own research, we inevitably have relied on these dominant theories to understand post-socialist spaces. Admittedly, this has helped us establish our academic careers, get published, and engage in intellectual conversations. At the same time, however, we are painfully aware that these dominant theories have a limited explanatory power, leaving many questions unanswered and many stories untold. Instead of only examining post-socialist education spaces through Western lens, we are interested in initiating our research from the position of comparative education's 'Other,' to pay attention to conflicts, failures, chances, incommensurabilities, irrationality, desires, pain, frailty and frivolity that are also, unavoidably, implicated in the educational phenomena of post-socialist spaces.
\end{abstract}

Our goal is to delink from this logic of coloniality by using three strategies. First, we engage in rethinking and rewriting the socialist past(s) through new and multiple frames to reveal potential possibilities for imagining multiple future(s). Second, we move to outline some relations of assumedly "different worlds" to question the very logic of modernity/coloniality. Third, we attempt to reflect on and reclaim our own positions as epistemic subjects who are capable of looking at the world from our own origins and lived experiences. While such an approach would normally be considered "beyond the scope of analysis" in many research studies (Blokker 2005, 511), we believe that it is critical in the process of delinking from a singular logic and path established by modernity/coloniality, thus having the potential to simultaneously open up the possibility for multiple histories and alternative visions of education in post-socialist spaces.

\title{
Complicating Histories: 'Posting' Socialisms
}

Comparative research on socialist and post-socialist transformations is often based on singular history writing that focuses on the eclipsing effects of totalitarianism, serving (both now and in 
the past) the geopolitical aims of the Cold War. Such approach ignores differences, transgressions, resistances, and the everyday spaces of life. In order to overcome the singular history constructed from the Cold War binary framework and in the colonial matrix of power, comparative research can contribute to writing histories with a critical, even revisionist, stance that runs against the grain of colonialism (Gregory 2001). 'Posting' socialism, a rethinking of the socialist past, would then mean to employ new and multiple frames from which these connections could be identified and made meaningful for understanding the present. Keeping in mind that colonial, pre-colonial, and post-colonial epochs are all possible defining features of post-socialist societies, the intertwining processes and phenomena as pre-socialist, socialist, and post-socialist could come to view. Revisionist histories could disrupt colonialist frames within which research about the socialist pasts and the post-socialist futures has been produced.

In the last two decades, we have seen an increase in the artistic engagements with socialist histories, ranging from highly acclaimed movies such as Goodbye Lenin! (Wolfgang Becker, 2001) and Underground (Emir Kusturica, 1995), to Eastern European writers such as Slavenka Drakulić, Aleksander Hemon, Gary Shteyngart, and others. Academic literature lagged behind, but nevertheless produced fascinating accounts of socialist life. In Everything Was Forever Until It Was No More, Alexei Yurchak (2006) engages in such a rewriting of the Soviet history by revealing paradoxes of Soviet life during the period of "late socialism" (1960s-1980s) through the eyes of the last Soviet generation. Drawing on rich ethnographic material (including personal diaries, memoirs, letters, interviews, photographs, jokes, music recordings as well as official publications of speeches, documents, newspaper articles, fiction, and film), Yurchak provides a powerful alternative to binary accounts that described the Soviet system as a dichotomy of official and unofficial culture, oppression and resistance, the state and the people, or public and private selves. He skillfully demonstrates how many young Soviet citizens genuinely valued the ideals and realities of socialism, but at the same time routinely transgressed and reinterpreted the norms and rules of the socialist state. As Yurchak (2006) explains,

the unanimous participation of Soviet citizens in the performative reproduction of speech acts and rituals of authoritative discourse contributed to the general perception of that system's monolithic immutability, while at the same time enabling diverse and unpredictable meanings and styles of living to spring up everywhere within it. (p. 29)

While some of Yurchak's work focuses on youth participation in popular culture, much of his research stems directly from youth experiences in education institutions, including schools, afterschool clubs, and universities. For example, Yurchak discusses how young people routinely attended the Palace of Pioneers, which offered large numbers of state-sponsored afterschool activities for children. The official goals of these afterschool activities were to bring up young pioneers to "struggle for the tasks of the Communist Party of the Soviet Union" and to instill in children the love for the "socially useful activity" (135). At the same time, however, many afterschool activities actively promoted the types of knowledge, critical judgement, and independent thought necessary to question authority and ideology of the state. In this context, both teachers and students participated in official rituals (within official structures), but they 
imbued these rituals with their own meanings. In other words, the system enabled - but did not determine - creative expressions and lifestyles among Soviet youth, revealing the agency of young people to participate simultaneously in reproducing and displacing the system. In a similar vein, Millei (2013) explored teacher subjectivities in Hungarian preschools through interviews with kindergarten teachers about their everyday work under socialism. She argues that kindergarten teachers were skillful in carefully navigating explicit political teaching to kindergarten children based on their professional judgement informed by a reasoning based on their child development knowledge. Similar to teachers working in other contexts, Hungarian teachers considered themselves primarily as professional experts rather than ideologues in the service of the socialist state.

More recently, research on socialist childhoods has attempted to complicate socialist past by questioning the assumptions regarding the unifying effects of schooling on children while reevaluating the child's position as an agent and epistemological subject. As a result, the stereotypical images of the child as an icon of socialist utopia, or the child as a traumatized victim of a repressive regime, give way to more ambivalent depictions, layered forms of knowledge, and a richer understanding of institutional settings and their effects on children in the former socialist countries. For example, Tesar's (2013) analysis of children's magazines published in Czechoslovakia in the 1970s and 1980s reveals how, on the one hand, these magazines functioned as public displays of ideological and political commitments, yet, on the other hand, they also served as a public facade behind which children and teachers could enjoy their increasingly varied lives and negotiate complex, non-hierarchical power relations. Similarly, Silova's (2016) analysis of Latvian early literacy textbooks, which were published during pre-socialist and socialist periods, shows how textbooks purposefully "located" children within particular political, cultural, and national landscapes, simultaneously constituting the child as well as the distinctions about who the child is and should be. Alongside the iconography of the socialist modernization and urbanization projects, for example, textbooks "located" the socialist Latvian child in the pre-socialist and even pre-modern (pagan) landscapes, thus enabling multiple and often inherently contradictory ideals and identities - socialist, nationalist, and pagan - to co-exist under socialism.

Finally, our own attempt of re-writing the socialist 'pasts' comes from our engagement in a collective biography project about the memories of socialist childhood and schooling (Millei, Silova, Piattoeva \& Aydarova, forthcoming). The focus is on examining how childhood and schooling were constituted and experienced in different socialist contexts - Hungary, Latvia, Russia, and Ukraine - by discussing the complex subject positions that we (as children under socialism) fashioned, inhabited, and exhibited. Building on Gonick \& Gannon's work $(2014,6)$, we used memory stories "to examine the ways in which individuals are made social, how we are discursively, affectively, materially constituted in particular moments that are inherently unstable." Our research on school uniforms (and especially the bows worn by schoolgirls) complicates the common understanding of children's political socialization under socialism as systematic and successful ideological indoctrination. Instead, we highlight children's subjectivity and agency in cleverly negotiating power relations and ideologies. In particular, we highlight 
how the ritual of tying a bow in one's hair could symbolize femininity and morality, an act of nationalist (and perhaps anti-Soviet) sentiment, a conformity to the socialist regime, an expression of aesthetic irony, or the demarcation of private/public spaces. Similar to Yurchak's (1997) notion of "pretense misrecognition" and Zizek's "cynical subject" (1991), the hidden curriculum of socialist upbringing ironically taught us to simulate adherence to the system and simultaneously suppress one's recognition of the act. This political act was not laden with the ridicule of or resistance to power, but rather with a lack of interest in it (see also Yurchak 1997, 162-163). In this manner, the reiterative practices of wearing bows created opportunities for us to learn and act political.

These are just a few examples of research that attempts to complicate the socialist 'pasts' by critically re-examining the assumed monolithic and authoritarian nature of childhood and schooling experiences. The consideration of multiple socialist trajectories and beings acknowledges the different histories, presents, and prospects of societies. This richness contributes to understanding "complex, fractured and foliated" spaces of post-socialist education transformations that can no longer be reduced to simple dichotomies (Gregory 2001, 614). While avoiding dichotomous (and often stereotypical) accounts of socialist practices and experiences, such research goes beyond rethinking and reinterpreting the past. It deepens our analyses and understandings of contemporary spaces, post-socialist or otherwise, and visions of new education utopias. Attention thus is placed on the heterogeneity of discourses, economies, politics, family and school cultures, highlighting the multiplicity of post-socialist spaces.

\section{Revealing Relations and Interconnections}

In addition to pluralizing histories and post-socialist paths, delinking strategies can highlight the relations between different "worlds," revealing that broader social changes do not take place in isolated post-socialist societies. Connecting and contrasting education phenomena inside and outside the post-socialist spaces and across time would provide opportunities to explore particularities of post-socialist spaces, thus contributing to theory-building in comparative education. They would also add to re-imagining the world that is typically constructed as neatly divided between (former) empires and colonized nations. This could reorient us towards understanding coloniality not as a property of certain countries or regions, but rather as multilayered, interconnected, and present in all societies (Morozov 2013). A shared effort between the postcolonial and post-socialist perspectives could create a critical language "pertinent enough to represent the complex histories of dependence ... and the consequences of these histories for the present moment in social, cultural, literal and economic terms" (Kolodziejczyk and Sandru 2012, 113).

By applying a relational approach, Bockman and her colleagues (Bockman 2011, Bockman \& Eyal 2002) offer a fascinating example of rewriting the history of neoliberalism. They refute the assumption that neoliberalism is a hegemonic project of the West that simply diffused and subordinated East European societies. Rather, they present neoliberalism as a hybrid body of knowledge, rationalities, and policies originated in socialism and developed through a decadeslong, but quickly forgotten, transnational dialogue in heterogeneous networks of economists 
from West and East. Bockman and Eyal (2002) highlight that socialist economies functioned as laboratories for economic knowledge production and were essential for providing evidence of the supremacy of market mechanisms. Simultaneously, this knowledge and the resources generated inside the networks let the participants of the transnational dialogue fight their own professional and political battles at home. Through manifold translations, the interests of Western and East European economists became aligned, and out of this alignment grew a distinct group of Eastern neoliberal economists who were ready to implement radical reforms once the opportunity arrived in 1989.

The potential contribution of the relational approach to comparative education opens new horizons for its central intellectual project, that is, to explore the interconnections and transfers of educational ideas and ideals across spaces and times (Cowen 2006). An example of this approach could be found in Daniel Tröhler's recent studies of the Cold War legacy of the OECD and the central policy threads of today, i.e. standardization, STEM (Science, Technology, Engineering and Mathematics) curriculum, statistical planning, educational accountability and output steering, large-scale comparative assessments, and incentivization (Tröhler 2013, 2014). He explores the educational reasoning that developed in the US in the direct aftermath of the Sputnik shock and points to its surprising similarity to the main pillars of socialist educational planning. This history sheds new light on the birth of the OECD's educational agenda as contingent on the transnational history of the Cold War (Tröhler 2013, 2014). It also shows how policies commonly perceived as emanating from a Western source developed in a symbolic relation to the parts of the world that since 1989, ironically, have been relocated to the receiving end of the global politics of educational borrowing and lending. The analytical approach adopted by Tröhler exhibits clear parallels to Said's notions of "overlapping territories" and "intertwined histories" as it unveils the mutually constitutive nature of 'West' and 'non-West' (see Go 2016).

Millei (2011) traces particular relations in between different worlds and times of early childhood education in the second phase of socialism in Hungary (1970s) and the curriculum framework after the turn of the $21^{\text {st }}$ century in neoliberal Australia. She compares the ways in which "the child" and his or her relations to the community (nation, society or local community) are conceptualized in curricula. She uses Foucauldian genealogy to compare ideas of "the child" and "community" embedded in the curriculum documents' respective discursive contexts of socialist and neoliberal political ideologies. She concludes that in both societies, although via different ways and for different reasons, children are governed through their communities under clear ideological regimes, which are not more or less regulating, but rather regulate differently. In another attempt to write a revisionist history, Imre \& Millei (2009) challenge the notion that Hungarian education was a monolithic neo-Stalinist version of "ideology expression." By connecting pre-socialist, socialist, and post-socialist trajectories, they write against the grain of Cold War historical misconstruction to show how cosmopolitan ideals waxed and waned, but provided a grounding ideology for socialist educational programs. They argue that these ideas were torn by those very initiatives vested with aspirations for a cosmopolitan outlook that sought to change educational spaces in post-socialist Hungary. 
In attempting to grasp the complexity of the current Russian educational discourse and its relations to other spaces, Piattoeva and Takala (2015) explore how the circulation of the crisis narrative in Russia epitomizes the relationality and interdependence of different global spaces. For example, the narrative of crisis began to disappear in Russia in the last decade, coinciding with Russia's recruitment by the World Bank to assist with moving knowledge around the postsocialist space. In contrast to other post-socialist countries, the OECD (1998) report on Russian education presented local policymakers and education practitioners as fully capable of implementing education reforms:

... the Russian Federation will be able to call upon the intelligence, dedication and wisdom of its own people ... Throughout the review, the team records its admiration for the commitment, ingenuity and positive motivation for change which it encountered in the great majority of the personnel it met with on-site visits. (pp. 9-10)

In the recent context, Russia appears as a new knowledge broker that moves education policies and practices from the West to the countries sponsored through READ (Russia Education Aid for Development trust fund focused on Angola, Armenia, Ethiopia, the Kyrgyz Republic, Mozambique, Tajikistan, Vietnam and Zambia) - all either former recipients of Soviet aid or located in the post-Soviet space which Russia perceives as its sphere of influence (e.g. Mäkinen 2016). In this relational space, Russia plays an active role in re-positioning itself at the interface between the post-socialist region (especially the Commonwealth of Independent States) and the international organizations. The post-socialist space is thus re-imagined and reinstated by one of its constitutive parts that turns the supremacy of "global best practices" to its own advantage. We see here the emergence of the variations of the orientalist theme - what Bakic-Hayden (1995) calls "nesting orientalisms", within the region to regain power.

Importantly, Russia welcomes the reshuffling and consequent polarization of post-socialist imageries and discourses as they serve its desire for re-integration in parts of the post-socialist region (Ministry of Finance of Russian Federation 2007). Ironically, the preliminary outcomes of this process resemble the unidirectional and hierarchical knowledge transfers that prevailed in the Soviet times when Russia functioned as an imperial centre that spread its norms and models to the peripheries. In the current process, we witness a complex re-colonialization through knowledge production and transfer in and through overlapping and interconnected spaces. While the new aid architecture regroups certain post-socialist countries as 'developing world,' thus completely erasing the distinction between the 'second' and 'third' worlds, the simultaneous positioning of Russia as a regional model revitalizes the distinctiveness of the post-socialist region as heterogeneous but still cohesive territory that requires a distinct role model to bridge the West and the post-socialist periphery. We can witness this role in the Russian efforts to become an agent of the global quality-of-outcomes policy (see Valverde 2014 for further discussion of the term).

\footnotetext{
5 Bakic-Hayden (1995) argues that the countries of Eastern Europe are fully aware of their own image in the "West" and play off "Eastness" against Europeanness, where Central Asia appears as more "East" or "other" than Eastern Europe or the Balkans.
} 
Dzenovska (2013) exposes another layer of complex and contradictory relations inherent in postsocialist transformations. She performs a post-colonial analysis of the rewriting of Latvian history that took place in the late 19th and early 20th century as part of post-socialist nationbuilding. In an effort to establish Latvia's historical presence in European modernity, Latvian historians appropriated the 17th-century colonial pursuits of the Duchy of Courland, which existed on the territory of present-day Latvia, ${ }^{6}$ into Latvian national history. However, rather than embracing colonial injuries - such as slave trade - Latvians rather sought to identify with colonial glories, especially the acquisition of the island of Tobago and a trading station on the River Gambia in West Africa. Dzenovska (2013) argues that Latvian identification with Europe's colonial past "not only renders visible the continued salience of coloniality in European politics but also illuminates the mechanisms through which Europe attempts to renew its moral superiority in the global arena by relegating colonialism to a past that Europe claims to have overcome" (394). This fascinating case reveals how Latvia, as one of the post-socialist objects of Europeanization, unsettles this project of deferral insofar as it adopts not only the discourses of free markets, human rights, and democracy as proof of Europe's civilizational superiority, but also strives "to embrace the colonial underside of European modernity, thus undermining attempts at keeping the two separate" (398). Making the colonial history of Europe visible thus disrupts coloniality because the political virtues of freedom, democracy and human rights, which Europe claims as its contribution to humanity, becomes reinserted into colonial expansion, slavery, and racism.

These studies emphasize the importance of going beyond the analysis of national and regional education histories in order to trace how contemporary political subjects are constituted in racialized and racializing fields of power relations in the global present. By making these relations visible we can thus see how different historical pasts and presents are closely intertwined, and in this process we can begin blurring the boundaries between different "worlds."

\section{Locating Ourselves in Research: 'Border Thinking'}

In addition to pluralizing socialist pasts, presents, and futures, as well as revealing the relations of different 'worlds,' we need to analyze the ways in which hierarchies of knowledge production also position academics and create symbolic closures imposed collectively on people. To make research politically different would mean to empower researchers to study their own conditions through methodologies that encourage anti-essentialist and diverse research approaches, as well as multiple articulations and representations. Escobar (2007), for example, argues for ethnographies that would avoid the epistemological traps of the studies of modernity. These studies would engage with "colonial difference and border thinking from the ground up, so to speak, for instance by engaging with gender, ecological, or economic difference" (see more in Escobar 2007, 192 and Vuola's work 2003). Similarly, Mignolo (2013) contends that this could

\footnotetext{
6 The Duchy of Courland, which was a vassal state to the Grand Duchy of Lithuania and later to the PolishLithuanian Commonwealth, existed in the territory of present-day Latvia between 1562 and 1726. The Duchy acquired two colonies between 1651 and 1658, when it lost them to the British.
} 
be done by engaging in "border thinking," that is thinking within the borders we are inhabiting "not borders of nation-states, but borders of the modern/colonial world, epistemic and ontological borders" (136-137). This means writing our own cultures, knowledges, and ways of being without constantly translating or comparing them to Western norms. Border thinking is thus grounded in a negotiation of inclusions and exclusions, of being at the same time outside and inside, where being is "rooted in irremovable contradictions - neither here nor there or both here and there at the same time" (Tlostanova, 2013).

We are often positioned in comparative education at the contact of blurred zones. Blurred zones or boundaries between different "worlds" can be produced through scholarship, as we have tried to illustrate in the sections above. But it can also occur through our own positionings as academics and practitioners in the field of comparative and international education. Depending on particular circumstances (and sometimes depending on who is present and what research topics are being addressed), we may be positioned as Western "experts" who can lend expertise in analyzing education phenomena and offer advice on education policy and practice in the region. At other times, we may also be viewed as nonWestern 'others' whose expertise is limited to explaining the local context through particular analytical frames. Indeed, we sometimes affiliate ourselves with international development agencies and non-governmental organizations (who are assumed to have the answers) and sometimes with national associations (who are assumed to seek the answers). During meetings and research projects, these positionings may also shift or we intentionally blur them, thus complicating conversations. This is a similar strategy to what Tlostanova and colleagues (2016) describe as 'feminist tricking'. This strategy is "not to curse and condemn, but rather to overcome the suffocating system existentially, intellectually and affectively" ( $p$. 7). In this way, our positionings become ambiguous and multi-layered leaving our colleagues to often wonder about where we belong. We understand this incongruity as our "right to opacity that is not enclosure within an impenetrable autarchy" and where opacity is a weave that far exceeds "the nature of its components" (Glissant 1997, 190 quoted in Tlostanova et al. 2016, 15). This kind of post-structural opacity and maneuvering helps to turn particular situations for our own benefit but also helps to delink, pluralize, or make opaque singular imagination about the positionings and knowledge of scholars originating from the postsocialist region. This is also our right, as Tlostanova (2013) exerts, because we do not "consciously choose border thinking. Rather it chose me [us]!"

Inclusions and exclusions could be approached by using Boaventura de Sousa Santos' (2009) differentiation between "strong questions" and "weak answers." Strong questions address the "roots and foundations that have created the horizon of possibilities among which it is possible to choose" (109), they produce a kind of perplexity around the very possibility of the question. Weak answers are those that fail to question the possibility of a question thus they remain in a colonial frame, in our case they maintain the singular view on post-socialist spaces created by 
modern/colonial epistemologies and globalization theories. The contact experience of these questions and answers are vested in power hierarchies, thus it is an experience of limits and borders. As de Sousa Santos $(2009,109)$ explains, "it is the contact experience that gives rise to the discrepancy between strong questions and weak answers." Therefore, it is especially urgent to question "how to maintain a transversal dialogue between the North, the South, and the different blurred zones in between, [and] how to hear each other and find intersections?" (Tlostanova et al. 2016, 5). Border thinking is one of the possible ways to do that.

One way to engage in "border thinking" is through autobiographic and autoethnographic research, which is becoming increasingly productive in disrupting the established binaries of being. It constitutes a general philosophical resistance to universal concepts and theories by adding to the multiplicity of voices and ways of narrating life experiences (Huddard 2008). Such research validates testimony as an important source of knowledge by directly challenging standard research methodologies that maintain the coloniality of knowledge and thus deauthorize the stories of the very people about whom research is conducted. As Hoagland (2009) rightfully asks, "when does a subject of knowing become a knowing subject?" (1). By troubling the usual subject-object relationships, these approaches bring into the conversation those who were denied subjectivity and the Western epistemological measure of rationality in dominant research endeavors.

The plurality of knowledge this type of research produces is different from what post-structural research understands as situated knowledges. While situated knowledge is powerful, it does not engage with the colonialism of Western epistemology (Escobar 2007). By contrast, research generated through "border thinking" is capable of extending the objects of study by bringing to light those stories, circumstances, and worldviews that have been previously erased by weak answers. This kind of research thus pluralizes knowledge and makes Western institutions of knowledge, which are generally seen as "the measure of all possible knowledges" (Mignolo \& Tlostanova 2007, 40), just one of the many possible knowledges and ways to understand the world.

Our own attempt to re-write the socialist pasts and decolonize post-socialist knowledge production comes from our engagement in a biography project about the memories of socialist childhood and schooling (Silova, Millei, \& Piattoeva, forthcoming). Through retelling our own and others' memory stories of socialist schooling and childhoods against the backdrop of official ideology and Cold War history writing, we explore how schooling was differently understood, lived, and felt by us as child participants. Through our narration of memories and artifacts of schooling, we bring scholars together to critically re-examine the assumed monolithic and authoritarian nature educational experiences during socialism. In addition to revealing contradictions and complexities that were ironed out by dominant Cold War history writing, we also strive to raise "strong questions" to which the answers bring forth multiple histories, stories, and subjugated knowledges that help us understand how schooling under different kinds of socialisms was lived in diverse ways. Such epistemological reframing of analyses enables us not only to disrupt the hegemony of dominant narratives about socialist and post-socialist childhoods 
and schooling, but also to actively engage in a de-colonial history writing and education research.

In another research project, Reimagining Utopias: Theory and Method for Educational Research in Post-Socialist Contexts, Silova, Sobe, Korzh, and Kovalchuk (forthcoming) mobilize an interdisciplinary group of researchers to critically reflect on their own positionalities in conducting research on education in post-socialist spaces. Collectively, this group exposes the limits of dominant conceptual frameworks and research methods, which hampered their own field research experiences in post-socialist education spaces. To overcome these challenges, the authors call for the importance of engaging in what Kenway \& Fahey (2009) call "a defiant research imagination," which is directed against the closure of meaning and towards emancipatory understandings of historical, political, and social realities (38). While acknowledging that power influences truth claims and by reflecting on the way power relations operate in their own research, some of these scholars argue that academic work should perhaps extend beyond the academic knowledge claims and also encourage activism on the part of the researchers. In other words, they emphasize the importance of multiple border-zones, including the spaces between academia and advocacy. Research conducted from these border-zones can produce what Gloria Ladson-Billings and Jamel Donnor (2008) have referred to as "a revolutionary habitus" (395).

\section{Conclusions}

In this article, first and foremost, we attempted to highlight that coloniality continues to operate in the comparative research imaginary. From this critical perspective, academic scholarship and policy research on post-socialist transformations have undoubtedly sustained the terms through which post-socialist spaces, people, and their experiences have been understood and targeted with agendas. In comparative education, the study of post-socialist education transformations has largely focused on tracing the complicated trajectories of the Western reform paths (such as outcomes-based education, privatization, decentralization, child-friendly schools, etc.) as well as broader concepts circulating internationally (such as education for democracy, equality or civil society). While effectively disrupting the notion of a "linear" transition, such studies nevertheless privilege the project of Western modernity and sometimes identify it as a "global" reform and trace its complicated trajectory locally (Silova, 2012). Even if the focus is on the "local" visions of education, it is always rooted in the necessity of transition and is compared - whether implicitly or explicitly - against that "global," further strengthening the established conceptual binaries.

Equally, such critical research still disregards both the common epistemological roots of the post-socialist and Western societal projects and the co-constitution and relationalities of East vs. West (Kangas \& Salmenniemi 2016). This is somewhat surprising since even the allegedly "Western" hegemonic ideology of neoliberalism has deep transnational roots as a body of thought grounded in years-long cooperation between economists from both sides of the Iron Curtain (Bockman 2011). The continuing ignorance of such entangled histories only reinforces 
the exclusionary knowledge produced about post-socialist societies and locates post-socialist countries mostly on the receiving side of knowledge transfer. To clarify our point here, we do not call for a new kind of regional studies focused on post-socialist spaces as objects of study; rather, we call for an understanding of post-socialist spaces as a geo-historical location with and within a distinct critical genealogy of thought (see similar argument of Escobar (2007) in relation to Latin America). As Mehta (2009) observes, "there is the erasure of voices as stories struggle to become part of a dominating discourse and the loss, or translated versions of those stories as they become part of the visible discourse" (1193). The erasure of these stories follows similar divisions to what de Sousa Santos (2007) describes as "abyssal thinking" following the lines of visible and invisible sides of the line. In this distinction, the other side of the line vanishes as reality and becomes non-existent and irrelevant since it falls outside of the accepted conception of inclusion, in our case the "Western" notion of desired trajectory of transition, knowledge production and being.

Post-colonial delinking offers a powerful challenge to dominant narratives and the linear trajectory of Western history and Western thoughts, "to change the terms and not just the content of the conversation" (Mignolo 2007, 459). Our methodological strategy to include juxta was productive in bringing these narratives to a momentary stop and to inserting alternative histories and forms of being, thinking, and feeling into dialogue. It enabled us to work within and against dominant forms of knowledge production by speaking with the mobilization of the 'wound' of coloniality (Mignolo \& Tlostanova, 2007), but resisting efforts of self-emancipation from the experience of domination which works for, and not against, integration into the same hierarchy. Thus, juxta also helped us to be in check of our own (re)productions of coloniality and desires of belonging to the dominant discourse, while watchfully undoing forms of knowledge and positionings that operate in our text.

Delinking inspires "action as counter-cultural and counter-hegemonic movements critiquing inequalities and long held power differentials" (Griffiths \& Millei, 2013, 163). It helps us to further complicate our understanding of multiple histories and presents, and ongoing reconfigurations of post-socialist educational spaces. It might also open the door for changing the hegemonic ideas of what knowledge and understanding are, and what the organization of society and education are and could be. Following Mignolo (2007, 459), we thus call for "terminological de-naturalization" that exceeds the binaries we explored in our text to create a "world in which many worlds can co-exist [and that] cannot be imagined and predicated on the basis of the "good abstract universal valid for all' but, instead, on pluri-versality as a universal project" (Mignolo \& Tlostanova 2006, 219). This kind of delinking fractures the hegemony of knowledge and creates ambivalence, opening spaces for multiple knowledges that exceed binary-thinking and singular positioning of scholars and practitioners in comparative education.

\section{Acknowledgements}

We would like to thank Inés Dussel, Jeremy Rappleye, and Will Brehm, as well as three anonymous reviewers and the editors of this special issue for their feedback on earlier drafts of this article. Nelli Piattoeva's work on this project was supported by the Academy of Finland 
grant 273874 .

\section{References}

Ahmed, Sarah 2004. "Affective economies.” Social Text 79, 22 (2): 117-139.

Altbach, Philip G. and Kelly, Gail P. 1978. Education and Colonialism. London: Transaction Books.

Bakic-Hayden, Milica. 1995. "Nesting Orientalisms: The Case of Former Yugoslavia." Slavic Review 54 (4): 917-931.

Balibar, Étienne. 2015. "War, Racism and Nationalism" (Interview with Étienne Balibar by Clement Petitjean). Online: http://www.versobooks.com/blogs/1559-etienne-balibar-war-racismand-nationalism

Balibar, Etienne. \& Wallerstein, Immanuel. 1991. Race, Nation, Class: Ambiguous Identities. New York: Verso.

Becker, Wolfgang. 2004. "Goodbye Lenin" [movie].

Blokker, Paul. 2005. "Post-Communist Modernization, Transition Studies, and Diversity in Europe.” European Journal of Social Theory 8 (4): 503-525.

Bockman, Johanna. 2011. Markets in the Name of Socialism. The Left-Wing Origins of Neoliberalism. Stanford: Stanford University Press.

Bockman, Johanna \& Eyal, Gil. 2002. "Eastern Europe as a Laboratory for Economic Knowledge: The Transnational Roots of Neo-Liberalism." American Journal of Sociology 108 (2): 310-352.

Bodine, Edward. F. 2005. "Radical Decentralization and the Role of Community in Polish Educational Reform." European Education 37 (1): 83-102.

Burawoy, Michael. 1999. "Afterword." In Uncertain Transition: Ethnographies of Change in the Postsocialist World, eds. M. Burawoy \& K. Verdery. Lanham, MD: Rowman \& Littlefield Publishers.

Central European University 2015. Central European University website. https://www.ceu.edu Chari, Sharad and Verdery, Katherine. 2009. "Thinking Between the Posts: Postcolonialism, Postsocialism, and Ethnography after the Cold War." Comparative Studies in Society and History 51 (1): 6-34.

Connell, Raewyn. 2007. Southern Theory: The Global Dynamics of Knowledge in Social Science. Unwin: Polity Press.

Cowen, Robert. 2006. "Acting Comparatively upon the Educational World: Puzzles and Possibilities." Oxford Review of Education 32 (5): 561-573.

Dabashi, Hamid. 2015. Can Non-Europeans Think? London: Zed Books.

Deleuze, Gill \& Guattari, Felix. 1987. A Thousand Plateaus: Capitalism and Schizophrenia (trans. Brian Massumi). Minneapolis: University of Minnesota Press.

De Sousa Santos, Boaventura. 2009. "A Non-Occidentalist West? Learned Ignorance and Ecology of Knowledge Theory." Culture \& Society 26 (7-8): 103-125.

De Sousa Santos, Boaventura. 2007. "Beyond abyssal thinking: From global lines to ecologies of knowledges.” Review XXX 1: 45-89. 
Dzenovska, Dace. 2013. "Historical Agency and the Coloniality of Power in Postsocialist Europe." Anthropological Theory 13: 394-416.

Eklof, Ben \& Seregny, Scott. 2005. "Teachers in Russia: State, Community and Profession.” In Educational reform in post-Soviet Russia, eds. B. Eklof, L. E. Holmes \& V. Kaplan. London and New York: Frank Cass.

Escobar, Arturo. 2007. "Worlds and Knowledges Otherwise." Cultural Studies 21 (2-3): 179210.

Fanon, Franz. 1967. Black Skin, White Masks. New York: Grove Press. Fimyar, Olena. 2010. "Policy Why(s): Policy Rationalities and the Changing Logic of Educational Reform in Postcommunist Ukraine. In Postsocialism is not Dead: (Re)reading the Global in Comparative Education, ed. I. Silova. Bingley, UK: Emerald.

Glissant, Édouard. 1997. Poetics of Relation. Ann Arbor, MI: University of Michigan Press. Go, Julian. 2013. "For a Postcolonial Sociology." Theory \& Society 42 (1): 25-55. Gobo, Giampietro. 2011. "Glocalizing Methodology? The Encounter between Local Methodologies.” International Journal of Social Research Methodology 14 (6): 417-437. Gonick, Marnina \& Gannon, Susan. 2014. Becoming Girl: Collective Biography and the Production of Girlhood. Toronto, ON: Women's Press. Gregory, Derek. 2001. "Post-Colonialism." In The dictionary of human geography, eds. R. Johnson, D. Gregory, G. Pratt and M. Watts. Oxford: Blackwell.

Griffiths, Tom Gary \& Millei, Zsuzsa, eds. 2013. Logics of Socialist Education: Engaging with Crisis, Insecurity and Uncertainty. Dordrecht, The Netherlands: Springer.

Hladik, Radim. 2013. A Theory's Travelogue: Post-Colonial Theory in Post-Socialist Space. http://www.postcolonial-europe.eu/essays/153-a-theorys-travelogue-post-colonial-theory-inpost-socialist-space.html

Hoagland S.L. 2009. Giving Testimony and the Coloniality of Knowledge. [unpublished manuscript].

https:/www.cavehill.uwi.edu/fhe/histphil/chips/archives/2009/docs/hoagland2009.aspx Hickling-Hudson, Anne. 1989. "Education in the Grenada Revolution, 1979-1983." Compare 19 (2): 95-114.

Hickling-Hudson, Anne. 2007a. "Cultural Complexity, Post-Colonialism and Educational Change: Challenges for Comparative Educators." International Review of Education 52: 201201.

Hickling-Hudson, Anne. 2007b. "Improving Transnational Networking for Social Justice: 20012004." In Common Interests, Uncommon Goals: Histories of the World Council of Comparative Education Societies and its Members, eds. Masemann, V., Bray, M., \& Manzon, M. Springer, Netherlands.

Huddart, David. 2008. Postcolonial Theory and Autobiography. New York, NY: Routleldge. Imre, Robert \& Millei, Zsuzsa. 2009. "Smashing Cosmopolitanism: The Neo-liberal Destruction of Cosmopolitan Education in East-Central Europe." Current Issues in Comparative Education. Special Issue on Cosmopolitanism. 12 (1): 76-85. IREX 2016. IREX website. https://www.irex.org Jackson, Alicia, \& Mazzei, Lisa. 2012. Thinking with Theory in Qualitative Research: Viewing Data Across Multiple Perspectives. Hoboken: Taylor \& Francis. 
Jusová, Iveta. 2016. "Situating Czech Identity: Postcolonial Theory and the 'European

Divident." In Czech Feminisms: Perspectives on Gender in East Central Europe, eds. Jusová, I.

\& Šiklová, J. Bloomington, Indiana: Indiana University Press.

Kangas, Anni \& Salmenniemi, Suvi. 2016. "Decolonizing Knowledge: Neoliberalism Beyond the Three Worlds." Distinktion: Journal of Social Theory. [ahead of print].

Kenway, Jane \& Fahey, Johannah. 2009. Globalizing the Research Imagination. New York:

Routledge.

Kołodziejczyk, Dorota \& Şandru, Cristina. 2012. "Introduction: On Colonialism, Communism

and East-Central Europe - Some Reflections.” Journal of Postcolonial Writing 48 (2): 113-116.

Kusturica, Emil. 1995. Underground [movie].

Ladson-Billings, Gloria \& Donnor, Jamel. 2008. The Moral Activist Role of Critical Race

Theory Scholarship. In The Landscape of Qualitative Research, eds. N.K. Denzin \& Y.S.

Lincoln. Thousand Oaks, CA: Sage Publications.

Lisovskaya, Elena \& Karpov, Vyacheslav. 2001. "The Perplexed World of Russian Private

Schools." Comparative Education 37 (1): 43-64.

Mahbubani, Kishore. 2001. Can Asians Think? Understanding the Divide between East and

West. Hanover, NH: Steerforth Press.

Maldonado-Torres, Nelson. 2007. "On the Coloniality of Being." Cultural Studies 21 (2-3): 240270.

Mehta, Sonia. 2009. "Big Stories, Small Stories: Beyond Disputatious Theory Towards

'Multilogue.' In International Handbook of Comparative Education, eds. R. Cowen \& A. M.

Kazamias. Dodrecht: Springer.

Mignolo, Walter. 2001. "Coloniality of Power and Subalternity." In The Latin American

Subaltern Studies Reader, ed. I. Rodríguez. Durham: Duke University Press.

Mignolo, Walter. 2011. The Darker Side of Western Modernity: Global Futures, Decolonial

Options. Durham \& London: Duke University Press.

Mignolo, Walter. 2007. "Delinking." Cultural Studies 21 (2): 449 - 514.

Mignolo, Walter. 2015. "Foreword: Yes, We Can by Walter Mignolo.” In Can Non-Europeans

Think?, H. Dabashi. London: Zed Books.

Mignolo, Walter. 2013. "Geopolitics of Sensing and Knowing: On (De)coloniality, Border

Thinking, and Epistemic Disobedience." Confero 1 (1): 129-150.

Mignolo, Walter \& Tlostanova, Madina. 2007. "The Logic of Colonality and the Limits of

Postcoloniality." The Postcolonial and the Global: Connections, Conflicts, Complicities, eds. R.

Krishnaswamy \& J. C. Hawley. Minneapolis: University of Minnesota Press.

Millei, Zsuzsa, Silova, Iveta, Piattoeva, Nelli \& Aydarova, Elena. Forthcoming. "The Politics of Bows: Political Subject Formation and Agency in Childhoods under (Post)Socialism." In Memories of (Post)Socialist Childhood and Schooling, eds. I. Silova, Z. Millei \& N. Piattoeva. Palgrave Macmillan.

Millei, Zsuzsa. 2013. "Memory and Kindergarten Teachers' Work: Children's Needs Before the Needs of the Socialist State." Globalization, Societies and Education 11 (2): 170-193. Millei, Zsuzsa. 2011. "Governing Through the Early Childhood Curriculum, 'The Child', and 'Community': Ideologies of Socialist Hungary and Neoliberal Australia." European Education 43 (1): 33-55. 
Ministry of Finance. 2007. Concept of Russia's Participation in International Development Assistance. Moscow: Ministry of Finance.

http://www.minfin.ru/en/financial_affairs/Dev_Assis/concept_rus/ accessed 27 August 2012 Morozov, Viatcheslav. 2013. "Subaltern Empire? Toward a Postcolonial Approach to Russian Foreign Policy." Problems of Post-Communism 60 (6): 16-28.

Mäkinen, Sirke. 2016. "In Search of the Status of an Educational Great Power? Analysis of Russia's Educational Diplomacy Discourse." Problems of Post-Communism [ahead of print]. Niyozov, Sarfaroz. 2004. "The Effects of Collapse of the USSR on Teachers' Lives and Work in Tajikistan." In The Challenges of Education in Central Asia, eds. S. P. Heyneman \& J.

DeYoung. Greenwich, CT: Information Age Publishing.

OECD 2003. Reviews of National Policies of Education: South Eastern Europe [Volume 1 \& 2]. Paris: France: OECD.

OECD 2001. Reviews of National Policies of Education: Latvia. Paris: France: OECD.

OECD. 1998. Reviews of National Policies for Education in the Russian Federation. Paris:

OECD.

Outhwaite, William \& Ray, Larry. 2005. Social Theory and Postcommunism. Oxford, UK:

Blackwell Publishing.

Perry, Laura. 2009. "American Academics and Education for Democracy in Post-Communist Europe." In American Post-Conflict Educational Reform: From the Spanish war to Iraq, ed. N. Sobe. New York, NY: Palgrave Macmillan.

Perry, Laura. 2003. Talking Democracy, Making Empire: Western Discourse of Post-Communist European Schooling. [Unpublished doctoral dissertation]. Chicago: University of Loyola Chicago.

Petersen, Eva Bendix. 2015. "What Crisis of Representation? Challenging the Realism of PostStructuralist Policy Research in Education." Critical Studies in Education 56 (1): 147-160. Piattoeva, Nelli. 2015. "Power as Translation in the Global Governance of Education." I Shaping of European Education Interdisciplinary Approaches, eds. M. Lawn \& R. Normand. Oxon: Routledge.

Piattoeva Nelli. 2010. Citizenship Education Policies and the State. Russia and Finland in a Comparative Perspective. Doctoral dissertation. Tampere: Tampere University, Acta Universitatis Tamperensis (http://acta.uta.fi /teos.php?id=11377)

Piattoeva, Nelli \& Takala, Tuomas. 2015. "Russia as a Returning Donor - Four Roles in Development Assistance to Education." Globalisation, Societies and Education 13 (3): 388-410. Quijano, Anibal. 2007. "Coloniality and Modernity/Rationality." Cultural Studies 21 (2-3): 168178.

Rappleye, Jeremy \& Komatsu, Hikaru. 2016. "Living on Borrowed Time: Rethinking Temporality, Self, Nihilism, and Schooling.” Comparative Education 52 (2): 177-201. Salecl, Renata. 2002. The Spoils of Freedom. Psychoanalysis and Feminism after the Fall of Socialism. London: Routledge.

Samoff, Joel. 1999. "No Teacher Guide, No Textbooks, No Chairs." In Comparative Education: The Dialectic of the Global and the Local, eds. R. F. Arnove, C.A. Torres. Oxford, U.K.: Rowman and Littlefield Publishers, Inc. 
Silova, Iveta, Millei, Zsuzsa \& Piattoeva, Nelli. Forthcoming. Memories of (Post)Socialist Childhood and Schooling. Palgrave Macmillan.

Silova, Iveta, Aydarova, Elena, Millei, Zsuzsa \& Piattoeva, Nelli. 2016. "Revisiting Pasts, Reimagining Futures: Memories of (Post)Socialist Childhood and Schooling" [special issue]. European Education 48(3): 159-240.

Silova, Iveta. 2012. "Contested Meanings of Educational Borrowing." In World Yearbook of Education 2012: Policy Borrowing and Lending in Education, eds. G. Steiner-Khamsi and F. Waldow. New York: Routledge.

Silova, Iveta. 2016. "The Futures of Post-Socialist Childhoods: (Re)Imagining the Latvian Child, Nation, and Nature in Educational Literature." In The Future(s) of Post-Socialism, eds. J. F. Bailyn, D. Jelača, D. Lugarić. Stony Brook, NY: The Stony Brook University Press. Silova, Iveta. 2014. "The Interplay of "Posts" in Comparative Education: Post-Socialism and Post-Colonialism after the Cold War." In Empires, Post-Coloniality and Interculturality: Comparative Education Between Past, Post, and Present, ed. L. Vegas. Rotterdam: Sense Publishers.

Silova, Iveta. 2010. "Re-discovering Post-Socialism in Comparative Education." In PostSocialism in not Dead: (Re)reading the Global in Comparative Education, ed. I. Silova. Bingley, UK: Emerald Publishing.

Silova, Iveta. 2009. "The Crisis of the Post-Soviet Teaching Profession in the Caucasus and Central Asia." Research in Comparative and International Education, 4(4): 367-384.

Silova, Iveta, Johnson, Mark \& Heyneman, Stephen. 2007. "Education and the Crisis of Social Cohesion in Azerbaijan and Central Asia." Comparative Education Review, 51(2): 159-180. Silova, Iveta \& Steiner-Khamsi, Gita. Eds. 2008. How NGOs react: Globalization and education reform in the Caucasus, Central Asia, and Mongolia. Bloomfield, CT: Kumarian Press.

Takala, Tuomas and Piattoeva, Nelli. 2012. "Changing Conceptions of Development Assistance to Education in Post-Soviet International Discourse." International Journal of Educational Development 32 (1): 3-10.

Takayama, Keita. 2011. “A Comparativist's Predicaments of Writing about 'Other' Education: A Self-Reflective, Critical Review of Studies of Japanese Education." Comparative Education 47 (4): 449-470.

Takayama, Keita. 2015. "Provincialising the World Culture Theory Debate: Critical Insights from a Margin." Globalization, Societies, Education 13 (1): 34-57.

Takayama, Keita, Heimans, Stephen \& Vegneskumar, Maniam. 2016. "Doing Southern Theory: Towards Alternative Knowledges and Knowledge Practices in/for Education." Postcolonial Directions in Education 5 (1): 1-25.

Tesar, Marek. 2013. "Socialist Memoirs: The Production of Political Childhood Subjectivities." Globalization, Societies, Education 11 (2): 223-238.

Tikly, Leon. 2004. "Education and the New Imperialism." Comparative Education 40 (2): 173198.

Tikly, Leon. 1999. "Postcolonialism and Comparative Education." International Review of Education 45 (5/6): 603-621. 
Tikly, Leon \& Bond, Tim. 2013. "Towards a Postcolonial Research Ethics in Comparative and International Education.” Compare: A Journal of Comparative Education 43 (4): 422-442. Tlostanova, Madina. 2012. "Postsocialist $\neq$ Postcolonial? On Post-Soviet Imaginary and Global Coloniality." Journal of Postcolonial Writing 48 (2): 130-142.

Tlostanova, Madina. 2013. Post-Soviet Imaginary and Global Coloniality: a Gendered Perspective

[Interview with Madina Tlostanova] http://www.kronotop.org/ftexts/interview-with-madinatlostanova/.

Tlostanova, Madina. 2015. "Can the Post-Soviet Think? On Coloniality of Knowledge, External Imperial and Double Colonial Difference." Intersections: East European Journal of Society and Politics 1 (2): 38-58.

Tlostanova, Madina, Koobak, Redi \& Thapar-Bjorkert, Suruchi. 2016. "Border Thinking and Disidentification: Postcolonial and Postsocialist Feminist Dialogues." Feminist Theory [ahead of print].

Tröhler, Daniel. 2013. "The OECD and Cold War Culture: Thinking Historically about PISA." In PISA, Power, and Policy: The Emergence of Global Educational Governance, eds. D. Meyer \& A. Benavot. Oxford: Symposium Books, pp. 141-161.

Tröhler, Daniel. 2014. "Change Management in the Governance of Schooling: The Rise of Experts, Planners and Statistics in the Early OECD." Teachers College Record 116: 1-26.

Valverde, Gilbert A. 2014. "Educational Quality: Global Politics, Comparative Inquiry, and Opportunities to Learn." Comparative Education Review 58 (4): 575-589.

Verdery, Katherine. 1996. What was Socialism and What Comes Next? Princeton, NJ: Princeton Academic Press.

Vuola, Elina. 2003. "Radical Eurocentrism. The Crisis and Death of Latin American Liberation Theology and Recipes for its Improvement."' In Interpreting the Postmodern. Responses to Radical Orthodoxy, eds. R. Ruether \& M. Grau. New York: T \& T Clark International. Yurchak, Alexei. 2006. Everything was Forever until it Was no More: The Last Soviet Generation. Princeton, NJ: Princeton University Press.

Yurchak, Alexei. 1997. "The Cynical Reason of Late Socialism: Power, Pretense, and the Anekdot." Public Culture 9 (2): 161-188. 